\section{Growth Response of Young Peach Trees to Distribution Pattern of Vegetation-free Area}

\author{
W.V. Welker ${ }^{1}$ and D.M. Glenn ${ }^{2}$ \\ Appalachian Fruit Research Station, Agricultural Research Service, U. S. \\ Department of Agriculture, Kearneysville, WV 25430
}

Additional index words. Prunus persica, orchard floor management, weed control

Abstract. Peach (Prunus persica L. Batsch) trees were grown for five growing seasons in uniform-sized vegetation-free areas arranged in three patterns within a tall fescue (Festuca arundinacea Schreb.) sod. Trees grown in a vegetation-free area arranged in a strip pattern grew better than trees grown either in the center or edge of a square. The distribution pattern of the vegetation-free area influenced growth during the first 4 years; however, at the end of 5 years, differences in canopy width and trunk crosssectional area were minimal. Thus, there is much latitude in distributing the available vegetation-free area as orchard floor management practices dictate.

Competition from weeds or sod can severely reduce growth of young peach trees (Arnold and Aldridge, 1980; Lange et al., 1969; Lord and Valch, 1973; Skroch et al., 1971). Herbicides can effectively control vegetation in established peach plantings (Arnold and Aldridge, 1980; Lange et al., 1969). The growth and nutrition of young peach trees are influenced by the size of the vegetation-free area provided the tree (Welker and Glenn, 1985, 1989). This study was established to evaluate the influence of the distribution pattern of the vegetation-free area on the growth of young peach trees.

Uniform-size 'Redhaven' trees $(\approx 1.0-\mathrm{cm}$ trunk diameter) on Halford seedling rootstock were planted in hand-dug holes $60 \mathrm{~cm}$ deep in a 3-year-old Kentucky 31 (K-31) tall fescue sod in Spring 1984 (Expt. 1). The trees were planted $4.5 \mathrm{~m}$ apart within rows spaced $6 \mathrm{~m}$ apart. Each plot consisted of three trees, with a guard tree between plots within the row. A randomized complete-block design with five replicates was used. All trees were pruned to a height of $1 \mathrm{~m}$ at planting. The soil type was a Hagerstown silt loam (fine, mixed Mesic Typic Hapludalf). A 6.8$\mathrm{m}^{2}$ vegetation-free area was established beneath each tree. A single application of $N$ (phosphonomethyl)glycine (glyphosate) at 2.2 $\mathrm{kg}$ acid equivalent (a.e.)/ha was applied to kill the grass before the trees were planted.

The vegetation-free areas were arranged in two patterns of equal area: 1) squares $2.6 \times$ $2.6 \mathrm{~m} ; 2$ ) strips $1.5 \times 4.5 \mathrm{~m}$ (width/length) (Fig. 1). The trees were planted in three locations in relationship to the vegetation-free

Received for publication 15 Nov. 1990. The cost of publishing this paper was defrayed in part by the payment of page charges. Under postal regulations, this paper therefore must be hereby marked advertisement solely to indicate this fact.

${ }^{\mathrm{I}}$ Weed Scientist.

${ }^{2}$ Soil Scientist. patterns: 1) in the center of the square; 2) at one side or edge of the square; or 3 ) in the center of the strip. Three weeks after planting, a residual herbicide treatment of $\mathrm{N}^{1}-(3,4-$ dichlorophenyl)-N,N-dimethylurea (diuron) plus 5,chloro-3-(1,1-dimethylethyl)-6-methyl2,4- $(1 \mathrm{H}, 3 \mathrm{H})$-pyrimidinedione (terbacil), each at $1.12 \mathrm{~kg}$ a.i./ha was applied as a tank mix. The same residual herbicide treatment was applied each spring to maintain the plots weed free. The area around the plots was maintained in K-31 sod.

A second experiment (Expt. 2), using 'Redhaven' on Halford seedling rootstocks, was established in 1985 adjacent to the first study. The K-31 sod was 4 years old. The same experimental design and postplanting treatments were established as in the first study. No irrigation was applied in either study. Fertilizer ( $\approx 85 \mathrm{~kg}$ of $10 \mathrm{~N}-4.4 \mathrm{P}-8.4 \mathrm{~K} /$ ha) was applied to the vegetation-free area in Spring 1986 and 1988 in Expt. 1; and in Spring 1988 and 1989 in Expt. 2. Canopy width $(\mathrm{CW})$ and trunk circumference were measured at the end of each growing season. Trunk circumference was measured $30 \mathrm{~cm}$ from the ground level and was used to calculate trunk cross-sectional area (TCA). All trees were trained to an open-center system and pruned accordingly each spring. Nitrogen was measured in fully expanded midshoot leaves (15 leaves per tree, three trees per plot) collected in late July each year. Leaves were washed in deionized water, dried at $60 \mathrm{C}$, and ground to pass a 40-mesh screen. Leaf $\mathrm{N}$ concentration was determined in a 100-mg sample using a micro-Kjeldahl digestion and titration method (Horowitz, 1970). Data were tested by analysis of variance with mean separation by use of Duncan's multiple range test.

The TCA and CW of trees grown at the edge of a vegetation-free square were less

Table 1. Effects of tree location and distribution pattern of the vegetation-free area on trunk crosssectional area and canopy width of young peach trees (Expt. 1, planted in 1984).

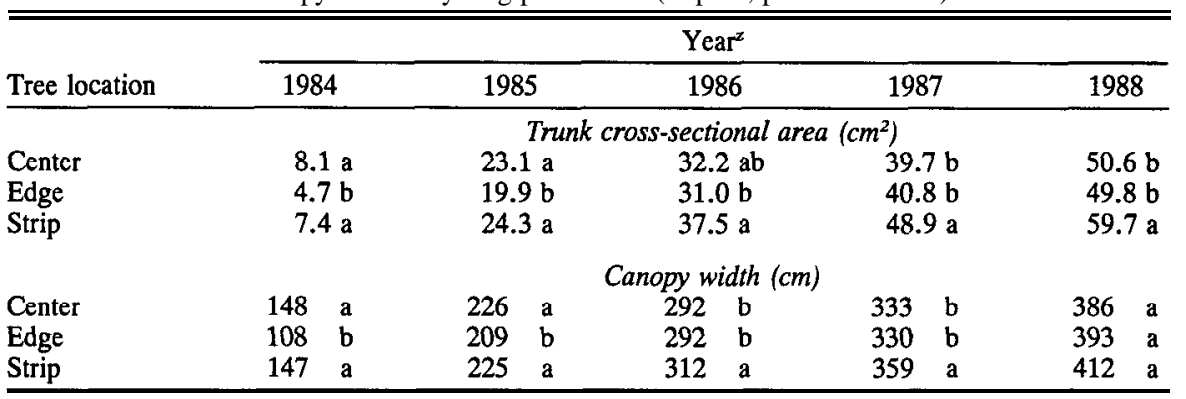

'Means separated within columns by Duncan's multiple range test, $P=0.05$.

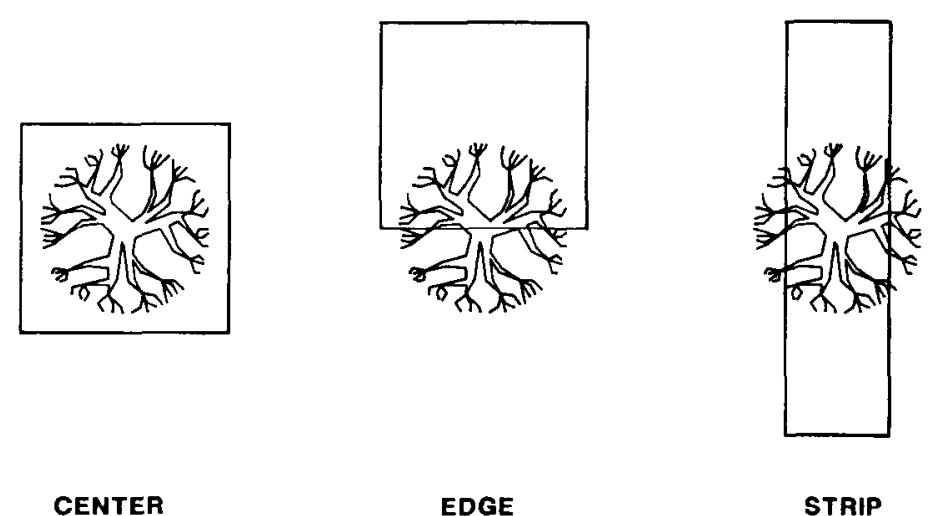

Fig. 1. Distribution pattern of vegetation-free area and tree location. 
Table 2. Effects of tree location and distribution pattern of the vegetation-free area on trunk crosssectional area and canopy width of young peach trees (Expt. 2, planted in 1985).

\begin{tabular}{|c|c|c|c|c|c|c|c|c|c|}
\hline \multirow[b]{2}{*}{ Tree location } & \multicolumn{9}{|c|}{ Year $^{\mathbf{z}}$} \\
\hline & \multicolumn{2}{|c|}{1985} & \multicolumn{2}{|c|}{1986} & \multicolumn{2}{|c|}{1987} & 1988 & \multicolumn{2}{|c|}{1989} \\
\hline & \multicolumn{9}{|c|}{ Trunk cross-sectional area $\left(\mathrm{cm}^{2}\right)$} \\
\hline Center & \multicolumn{2}{|c|}{$6.4 \mathrm{a}$} & \multicolumn{2}{|c|}{$21.4 \mathrm{a}$} & \multicolumn{2}{|c|}{$29.6 \mathrm{ab}$} & $41.2 \mathrm{ab}$ & \multicolumn{2}{|c|}{58.3 a } \\
\hline Edge & \multicolumn{2}{|c|}{$3.9 \mathrm{c}$} & \multicolumn{2}{|c|}{$16.7 \mathrm{~b}$} & \multicolumn{2}{|c|}{$25.6 \mathrm{~b}$} & $37.1 \mathrm{~b}$ & \multicolumn{2}{|c|}{$55.0 \mathrm{a}$} \\
\hline \multirow[t]{2}{*}{ Strip } & 4.4 & & 20. & & 31. & & $44.1 \mathrm{a}$ & 61.1 & 1 a \\
\hline & \multicolumn{9}{|c|}{ Canopy width $(\mathrm{cm})$} \\
\hline Center & 113 & $\mathbf{a}$ & 220 & a & 288 & a & 341 & 410 & a \\
\hline Edge & 86 & $\vec{b}$ & 196 & b & 277 & a & 331 & 405 & a \\
\hline Strip & 96 & $\mathrm{~b}$ & 212 & a & 298 & a & $359 \quad$ a & 418 & a \\
\hline
\end{tabular}

${ }^{2}$ Means separated within columns by Duncan's multiple range test, $P=0.05$.

than those of trees grown either in the center of the vegetation-free square or strip during the first two growing seasons in both experiments (Tables 1 and 2). During the last 3 years of both studies, the TCA and CW tended to be largest for the strip treatment, and peach tree growth was not affected by tree placement in the vegetation-free square treatment. There was no difference in leaf $\mathrm{N}$ concentration (range $2.4 \%-3.3 \%$, Expt. $1 ; 2.6 \%$ $3.8 \%$, Expt. 2) due to the tree placement, except for the first year in both experiments, where the leaf $\mathrm{N}$ concentration was less in those trees planted at the edge of the vegetation-free area $(3.4 \%$ and $3.6 \%$, respectively) than in those from the center $(3.9 \%$ both years) or those from the strip (3.8\% and $4.0 \%$, respectively). The initial growth suppression of trees growing at the edge of the vegetation-free square, compared with those in the center of the vegetation free square, was overcome by the 3rd year, indicating that the root system of the tree was fully using the vegetation-free area provided. Fertilizer applied in 1986 and 1988 in Expt. 1 and 1988 and 1989 in Expt. 2 increased leaf $\mathrm{N}$ relative to 1987 when no fertilizer was applied; however, treatment effects on leaf $\mathrm{N}$ were nonsignificant. The uniform lack of treatment response to fertilizer application indicates that the distribution pattern of the vegetation-free area had no effect on the ability of the peach tree to use available nutrients within the vegetation-free area. Peach trees grown in the center of the square treatment were separated by $1.9 \mathrm{~m}$ of sod within the row, and trees grown in the strip treatments had no barrier between trees. Trees grown in the strip treatments had a significantly larger TCA in Expt. 1 and tended to have a higher TCA in Expt. 2 during the last 3 years, indicating that peach trees may be less sensitive to competition from another peach tree than they are to competition from grass. We have shown in previous studies that K-31 sod reduces fine root production in peach (Glenn and Welker, 1986). These studies suggest that the most favorable distribution pattern of a constant size vegetation-free area for maximum growth of young peach trees would be in a strip within the tree row, rather than in a square pattern. These studies also suggest that there is latitude in the configuration of a constant size vegetation-free area in devising management strategies in mature peach trees with minimal impact on tree growth. tall fescue sod. HortScience 24:117-119.

Horowitz, W. (ed.). 1970. Official methods of analysis. 11th ed. Assn. Offic. Anal. Chem., Washington, D.C. p. 17-18.

Lange, A.H., J.C. Crane, W.B. Fisher, K.O. Roberts, and C.L. Elmore. 1969. Pre-emergence weed control in young deciduous fruit trees. J. Amer. Soc. Hort. Sci. 94:57-60.

Lord, W.J. and E. Vlach. 1973. Response of peach trees to herbicides, mulch, mowing, and cultivation. Weed Sci. 21:227-229.

Skroch, W.A., T.J. Sheets, and J.W. Smith. 1971. Herbicide effectiveness, soil residues, and phytotoxicity to peach trees. Weed Sci. 19:257260.

Welker, W.V. and D.M. Glenn. 1985. The relationship of sod proximity to the growth and nutrient composition of newly planted peach trees. HortScience 20:417-418.

Arnold, C.W. and J.H. Aldrich. 1980. Herbicidal effects on peach seedling growth and weed control. HortScience 15:293-294.

Glenn, D.M. and W.V. Welker. 1986. Peach root development and tree hydraulic resistance under
Welker, W.V. and D.M. Glenn. 1989. Sod proximity influences the growth and yield of young peach trees. J. Amer. Soc. Hort. Sci. 114:856859. 